\title{
Challenges of Teaching English Language Classes of Slow and Fast Learners in the United Arab Emirates Universities
}

\author{
Bilal Zakarneh $^{1}$, Najah Al-Ramahi ${ }^{1} \&$ Mahmoud Mahmoud $^{2}$ \\ ${ }^{1}$ Ajman University, UAE \\ ${ }^{2}$ University of Nizwa, Oman \\ Correspondence: Bilal Zakarneh, College of Humanities and Sciences, Ajman University, United Arab Emirates. P.O. \\ Box: 346, Ajman, UAE.
}

Received: November 15, 2019

Accepted: December 31, 2019 Online Published: February 6, 2020

doi:10.5430/ijhe.v9n1p256

URL: https://doi.org/10.5430/ijhe.v9n1p256

\begin{abstract}
One of the greatest challenges experienced by teachers teaching students who learn English as a foreign or a second language is teaching a class consisting of fast learners and slow learners commonly referred to as mixed-ability classes. The present study investigates challenges experienced by teachers of English language classes encompassing slow learners and fast learners. Data was collected using survey questionnaire and analyzed using Microsoft excel. Results revealed that teachers of English language experience several challenges: mixed-ability class tend to be uncooperative and fast learners get bored easily; challenges in planning for the lesson to teach a mixed-ability class; challenges in creating appropriate work-materials for the mixed-ability class; lack of best approaches to manage mixed-ability class; challenges in getting attention of all learners in a mixed-ability class; and frustration when teaching mixed-ability classroom due to low motivation of weak students.
\end{abstract}

Keywords: fast learners, slow learners, mixed-ability class, instructional methods

\section{Introduction}

It has been suggested in the extant literature that one of the greatest challenges experienced by teachers teaching students who learn English as a foreign language is teaching a class consisting of fast learners and slow learners commonly referred to as mixed-ability classes (Al-Shammakhi, \& Al-Humaidi, 2015). According to Hedge (2000), mixed-ability classes have students with varying abilities in learning language, and that may be the key underlying cause of challenges experienced by teachers who teach mixed-ability classes. Emphasizing the differences in abilities among students in mixed-ability classes, Hedge (2000) argued that students differ in their cognitive abilities and this consequently affects their language learning abilities. Hedge (2000) identified learners as high-ability learners (fast learners); moderate-ability learners and low-ability learners (slow learners) of foreign language. Supporting this view, Chapman and King (2003) opined that in mixed-ability foreign language classes, students with most difficulties in learning language tend to experience severe to moderate spelling and reading difficulties. Chapman and King (2003) further noted that other learners without history of reading and spelling difficulties might also find it challenging to learn foreign language. Though researchers acknowledge that teachers of mixed-ability classes experience challenges, few have investigated these challenges within the United Arab Emirates (UAE) context. The present study seeks to contribute to the literature in second-language learning by investigating and highlighting possible challenges teachers of English language classes encompassing slow learners and fast learners in the UAE universities may experience and possible solutions as indicated in the academic literature. The rest of the paper is organized as follow: research question guiding the study; a review of literature in relation to what characterizes mixed-ability classes; research methodology detailing how the study was conducted; research findings based on the participants' responses, and a discussion of the findings; and a conclusion and recommendations to teachers of mixed-ability foreign language classes.

\section{Research Questions}

This study addresses the following questions related to learning of foreign language:

1. What are the characteristics of mixed-ability classes?

2. What are the characteristics of slow and weak leaners, and fast and bright learners? 
3. What are the challenges experienced by English teachers of mixed-ability classes?

4. What are the instructional methods that can benefit learners of English with mixed abilities learning in mixed-ability classes?

\section{Literature Review}

Mixed-ability classes consist of fast learners and slow or weak learners (Ansari, 2013). According to Ansari (2013), learners in mixed-ability classes have different levels of learning and achievements. These learners differ in weaknesses and strengths. These students differ in their abilities, including in fluency and accuracy, grammatical knowledge, productive and receptive skills and the size of vocabulary (Valentic, 2005 Sailaja,2018).

\subsection{Slow Learners of Language}

Psychologists and educational researchers use different terms to describe and refer to slow learner students. For Muppudathi (2014) a slow learner is a student who has the ability to gain all the necessary academic skills with the exception that her/his depth and rate is below that of an average learner. In view of Borah (2013), slow learners are students with slightly below average cognitive abilities. They may fail to excel in some subjects or classes. However, this does not qualify them to be identified as disabled students as they are normal students who cannot study under traditionally accepted educational system (Borah, 2013). According to Borah (2013), slow learners could be identified with five characteristics. Firstly, these learners work very slowly and lack the ability to undertake complex or multifaceted problems. Secondly, slow learners demonstrate poor performance in school and show recurrent immaturity in their relation with other learners. Thirdly, these learners are known to be slow in mastering academic skills, such as spelling rules or timetables. Fourthly, these learners are said to lack the ability to convey what they learned between tasks; and lose track of time and events. Lastly, these learners are reported to create and keep track of long-term goals. Supporting this view, Billy (2016) identified ten characteristics that are associated with slow learners: difficulty in following multi-step directions; functioning at the ability significantly lower than the grade level; being prone to creating immature interpersonal relationships; scoring at consistently low on academic and achievement tests; poor self-image; smart at "hands-on" material (manipulative or lab activities); working on tasks at a relatively slower rate than an average student; lacking long-range goals and living in the present; and having few internal strategies (e.g., generalizing information, difficulty transferring and organizational skills. Elsewhere, Sparks, Ganschow and Javorsky (1998) suggested that students who exhibit learning problems in foreign language have subtle or overt native language learning difficulties and differences that affect their ability to learn a foreign language. In the same vein, Lescano (1995) noted that the weakest skills among slow learners are reading and writing. In a similar study, Khan (2008) noted that factors that contribute to students being slow learners include: lack of secure environment; lack of emotional growth; absenteeism; large class size; untrained teachers; and limited opportunities. Within language learning context, it was argued by Billy (2016) that factors that contribute to one being a slow learner, include inadequate use of language learning strategies, and past negative learning experiences leading to one losing interest. This is the main challenge for language instructors who are not equipped with the required skills and teaching methods to deal with mixed-ability classes (Ansari, 2013). Therefore, instructors in mixed-ability classrooms need to be given continuous training to overcome the challenges of the diverse learners (Al-Subaiei, 2017).

In this study, the term slow learners is used interchangeably with weak students within the language learning context to refer to the learners with the ability to gain all the necessary academic skills through a depth and rate below that of an average learner/student as defined by Muppudathi (2014); and as leaners who exhibit learning problems in foreign language have subtle or overt native language learning difficulties and differences that affect their ability to learn a foreign language (Sparks, Ganschow \& Javorsky, 1996).

\subsection{Fast Language Learners}

It has been suggested in the extant literature that fast and bright students tend to be good language learners. Oxford (1990) believes that these learners can learn without the teacher's guidance and that these learners can use a teacher as a resource to achieve maximum learning. Oxford (1990) noted that these learners do not see a teacher as "all-knowing" rather they see the teacher as an equal partner or facilitator. Rubin and Thomson cited in Nunan (2000) also held that fast learners or good language learners have the following characteristics: organize information about language; find their own way; creative and experimental with language; create their own opportunities and identify strategies to use language outside and inside the classroom; develop strategies to make sense of second language without seeking to understand every work; learn to live with uncertainty; use mnemonics (word associations, rhymes) in recalling what is learned); make errors work; use linguistic knowledge to master a second language; let the context 
(knowledge of the world and extra-linguistic knowledge) to help them comprehend language; learn production techniques; learn chunks of language as formalized routines and wholes to enable them perform beyond their level of competence; learn to make fast and intelligent guesses; learn different styles of writing and speech and to vary language based on the situation's formality. Other researchers (e.g., Brown, 2000; Oxford, 1990) indicated that fast leaners live with uncertainty, take risks, are motivated to learn, use previous schemas to learn language, and use solid strategies to learn language. For Billy (2016) fast learners have good academic skills, high intelligence and enjoy the learning process. Billy (2016) argued that these learners could apply these skills of learning subjects by looking for patterns to learn a language. For Lightbown and Spada (1997) good and fast language learners possess the following characteristics: willing and accurate guessers; look for patterns; willing to make mistakes; communicate even without language; enjoy grammar; pay attention to standards; practice whenever possible; and have good self-confidence and self-image. Elsewhere, Hedge (2000) identified fast learners as "self-directed learners". According to Hedge (2000), fast learners have autonomous and good strategies in place. Hedge (2000) hinted that these learners do not follow blindly everything said by the teacher rather they process information provided and make it their own. Hedge (2000) noted that as self-directed learners, fast learners are often motivated to learn language and are willing to give in their best to accomplish any task. Hedge (2000) emphasized that 'Self-Directed Learners' display the following characteristics: know how to utilize resources independently; work productively with teachers to achieve their objectives; know their needs; learn both outside and inside the classroom; adjust learning strategies accordingly; divide and manage time in learning properly; learning with active thinking; and work and coordinate with the teacher to learn language. Supporting this view, Hedge (2000) further suggested that fast learners of language are autonomous and are both meta-cognitively and cognitively aware of the role they need to play in learning language; monitor their learning; create opportunities to learn; and attempt to manage the learning process outside and inside the classroom.

\subsection{Past Literature on Challenges Experienced by Weak and Bright Students in Learning Language}

Studies have documented various challenges encountered by foreign language learners: low/slow learners and high/fast foreign language learners.

Some empirical studies investigated within American and British contexts have demonstrated at the post-secondary and secondary levels that while good foreign language learners exhibit significantly stronger native written and oral language skills and foreign language aptitude, weak foreign language learners experience challenges in acquiring written and oral language skills and foreign language aptitude skills and knowledge. Other challenges experienced by weak learners of foreign language as revealed in American and British studies include difficulties acquiring native language skills; poor foreign language grades; anxiety in foreign language learning; low proficiency in foreign language; low self-perceptions by weak language students; reading comprehension impairment; difficulty in word level fluency and decoding (Hordiinko \& Lomakina, 2015; AI-Subaiei, 2017; Chou \& Luo, 2003; Svärd (2006;Baker, 2002; Ganschow et al., 1991; Sparks et al., 1992; Humes-Bartlo, 1989; Service, 1992).

For example, Hordiinko and Lomakina (2015) examined the challenges experienced by English teachers when teaching students in mixed-ability classes and the probable causes of these challenges. Results revealed that teachers find it challenging to strike a balance between weak, average and fast learners as weak students tend to feel demotivated and develop inferiority complex and this affects participation in class. Hordiinko and Lomakina (2015) noted that weak students tend to lack basic knowledge of the subject and this makes them feel frustrated when in mixed-ability classrooms.

Similarly, AI-Subaiei (2017) used a sample of 33 participants to investigate challenges experienced by English teachers when teaching mixed-ability classes and the methods used to cope. Results revealed that teachers of mixed-ability English language classes tend to experience challenges that range from class management and motivation issues, and challenges related to inadequate learning materials to teach learners in mixed classes and that teachers find it challenging to meet the needs of learners with different abilities. It was noted that these challenges could be mitigated using differentiation strategies.

In a similar study, Chou and Luo (2003) used a sample of 212 participants to explore the effects of mixed-ability and levelled ability grouping on motivation of learners of English in Taiwanese elementary education. The study also sought to determine the attitudes of participants towards mixed and levelled groups systems. The study finding revealed that students prefer levelled grouping system against mixed ability grouping. It was also noted that the majority of participants felt uncomfortable when placed in lower level of English classes. It was revealed that fast learners or learners with high level of proficiency in English were worried about studying alongside those with low level of proficiency in English in lower level mixed-ability classes. 
Svärd (2006) interviewed upper secondary teachers in an attempt to investigate challenges faced by upper secondary English teachers when teaching mixed-ability classes and ways to overcome these challenges. Challenges of teaching mixed-ability classes were identified as dealing with learners with different learning abilities; difficulty of getting attention from all learners; poor motivation by learners; frustration on the part of the teacher; uncooperativeness of learners; and difficulties in planning lessons and creating work-material. Suggested ways of overcoming challenges experienced by teachers of mixed-ability English classrooms were reported as creating good learning atmosphere, structure and setting routines, and differentiation and motivation.

In another study on the challenges of teaching language to learners with mixed abilities, Baker (2002) reported the challenges as differences in ability levels among students; attention issues; low motivation by students, and frustration on the part of teachers in their attempt to meet the demands of learners with mixed abilities.

Other studies demonstrated that differences in foreign language aptitude and native language skills pose challenges to teachers who deal with mixed-ability classes.

Studies have also suggested that slow students in learning language tend to demonstrate poorer native language skills than those students with strong language skills (Ganschow et al., 1991; Sparks et al., 1992; Humes-Bartlo, 1989; Service, 1992).

In a related study by Sparks et al. (1992a), a foreign language aptitude and native language measures were administered to first-year foreign language learners in high schools. This study divided students into two groups: based on foreign language teacher's recommendation; and first-quarter foreign language grade (i.e., high-risk learners who scored grades D or F or low-risk learners who achieved grades A or B. Low-risk foreign language learners reported significantly greater foreign language aptitude, and stronger syntactic and orthographic or phonological skills than high-risk foreign language learners did. In a similar study by Sparks et al. (1992b), a comparison was made between 15 students diagnosed with a learning disability and enrolled with the first language classes and high-and low-risk learners on similar testing measures. Finding revealed significantly greater foreign language aptitude and stronger orthographic/phonological and syntactic skills by low-risk foreign language learners compared to high-risk foreign language learners. No statistically significant differences were observed on most foreign aptitude and native language measures between learning difficulty groups and high-risk-groups. However, significant differences were noted in spelling in the two groups of learners. Humes-Bartlo (1989), foreign language educator, noted that poor foreign language learners demonstrate milderlcdh deficits in native language skills than good foreign language learners. Similarly, Service (1992) opined that the ability to compare semantic and syntactic structures and orthographic/phonological tasks by learners predict skill in second language acquisition/learning.

Studies have also suggested that low score in foreign language grades is one of the challenges encountered by weak language learners and this pose a challenge to teachers teaching mixed-ability classes. For example, in a study by Sparks and Ganschow (1996), it was noted that significant differences exist on measures of foreign language aptitude and native language skills among students who recorded grades A, B, C, D and F in high school and first-year foreign language courses. It was also observed that students who achieved grade A's had higher scores on those measures compared to those who achieved grades B's who in turn had higher scores than those who achieved grade C's. Other studies also reported that students who obtain higher foreign language grades have significantly stronger foreign language aptitude skills and native language skills than those who obtain lower foreign language grades (Sparks \& Ganschow, 1995; Ganschow et al., 1991; Ganschow et al., 1994; Ganschow \& Sparks, 1996).

Sparks, Ganschow and Patton (2005) used a sample of 100 co-ed learners and 154 women to determine the best predictors of foreign language grades among students undertaking first-year high school foreign language courses. Results revealed that students' eight grade score and grade on the foreign language aptitude measure and native language spelling were significant predictors of foreign language grade. In this study, Sparks, Ganschow and Patton (2005) hypothesized that these variables offered support for Linguistic Coding Differences Hypothesis (LCDH) on the ground that English class requires learners to use written language skills (writing and reading) and oral language skills (speaking and listening) for classroom success.

\section{Methodology}

\subsection{Research Design: Survey}

Data used in the present study was collected from 100 teachers of foreign language (English) in the United Arab Emirates (UAE) universities using a questionnaire. This tool was deemed appropriate because of its associated advantages of collecting enormous data in short period of time and the ease with which it can be filled online and returned for analysis. Moreover, questionnaire has the following advantages: (a) easy to be managed as the same 
questionnaire can be distributed to a large number of people; (b) more convenient for people as they can take their time to complete it; and (c) less bias as it is asks the same questions for all respondents (May, 1993).

Accordingly, a structured questionnaire was used to collect responses to closed-ended questions posed to participants regarding the possible challenges facing them as teachers of foreign language when teaching mixed-ability classes. Questions contained in the questionnaire guaranteed the respondents' anonymity and made it easier to mail the questions to study participants via email. Anonymous feedback from study participants encouraged openness and honesty, thus contributed to the reliability of data collected. Closed-ended questions also resulted in data that was analysed quantitatively. These questions were formed based on previous similar studies that highlighted possible challenge faced by teachers of foreign languages teaching slow and fast leaners in different contexts around the world.

A five-point Likert scale was used to score the closed-ended questions. Likert Scale questionnaire is one of the most widely used tools in researching popular opinion. It is a psychometric testing to measure viewpoints, attitudes and opinions toward a particular subject, e.g., person, thing or idea. The responses to these questions ranged from 1 to five with 5 denoting strong agree and 1 denoting strongly disagree. The researcher analysed these responses to show challenges faced by teachers of weak students of foreign language.

The questionnaire was validated for clarity and relevance by 10 experts from the College of Humanities and Sciences at Ajman University. Then it was sent to ten teachers as a pre-test for the research instrument. Accordingly, modifications were made in the structure of some sentences, a few questions were broken into two statements and some sentences were deleted for greater clarity.

A cover page was attached to inform the respondent the following: personal information; aims of the research; the importance of the survey; and assurance of anonymity and confidentiality. The questionnaire consisted of three parts. The first part investigated the demographic information about the participants such as gender and years of experience; the second part was about challenges that teachers face in mixed-ability classes; and the third part included open questions and asked teachers to state any affective strategies they apply in their classes in order to overcome those challenges.

\subsection{Sampling: Convenient Sampling}

In this study, convenient non-probability sampling technique was adopted. The use of the convenient non-probability sampling technique enabled the researchers to narrow down to specific target population of the study: teachers teaching English in the UAE universities. It meant that the researchers could only select teachers conveniently, especially those who could demonstrate the willingness to participate in the study. The sample of teachers was selected to represent a population of teachers of slow and fast foreign language students in the UAE universities which were located in Abu-Dhabi; Dubai and Ajman. Survey questionnaire was mailed to the study participants. The research population was made up of $50(50 \%)$ male and $50(50 \%)$ female English teachers. This sample size was deemed large enough to improve readers' confidence in the findings of the study, improve its statistical power, and allow for generalizability of the study findings to teachers of mixed-ability classes consisting of slow and fast students in the UAE universities.

\subsection{Data Analysis}

Data analysis was undertaken using Microsoft excel. This involved quantifying challenges experienced by teachers of slow and fast foreign language students in UAE universities. This involved analysing and presenting responses scored on the five-point Likert scale in form of graphs and tables.

\section{Results}

Participants consented to challenges identified in the literature as representing the challenges experienced by teachers when teaching language to Arab learners of English in mixed-ability classes. For example, majority of participants agreed (strongly agreed-30.8\% and agreed-42.5\%) that it is challenging to meet the demands of fast and slow learners in a typical classroom (Figure 1). 


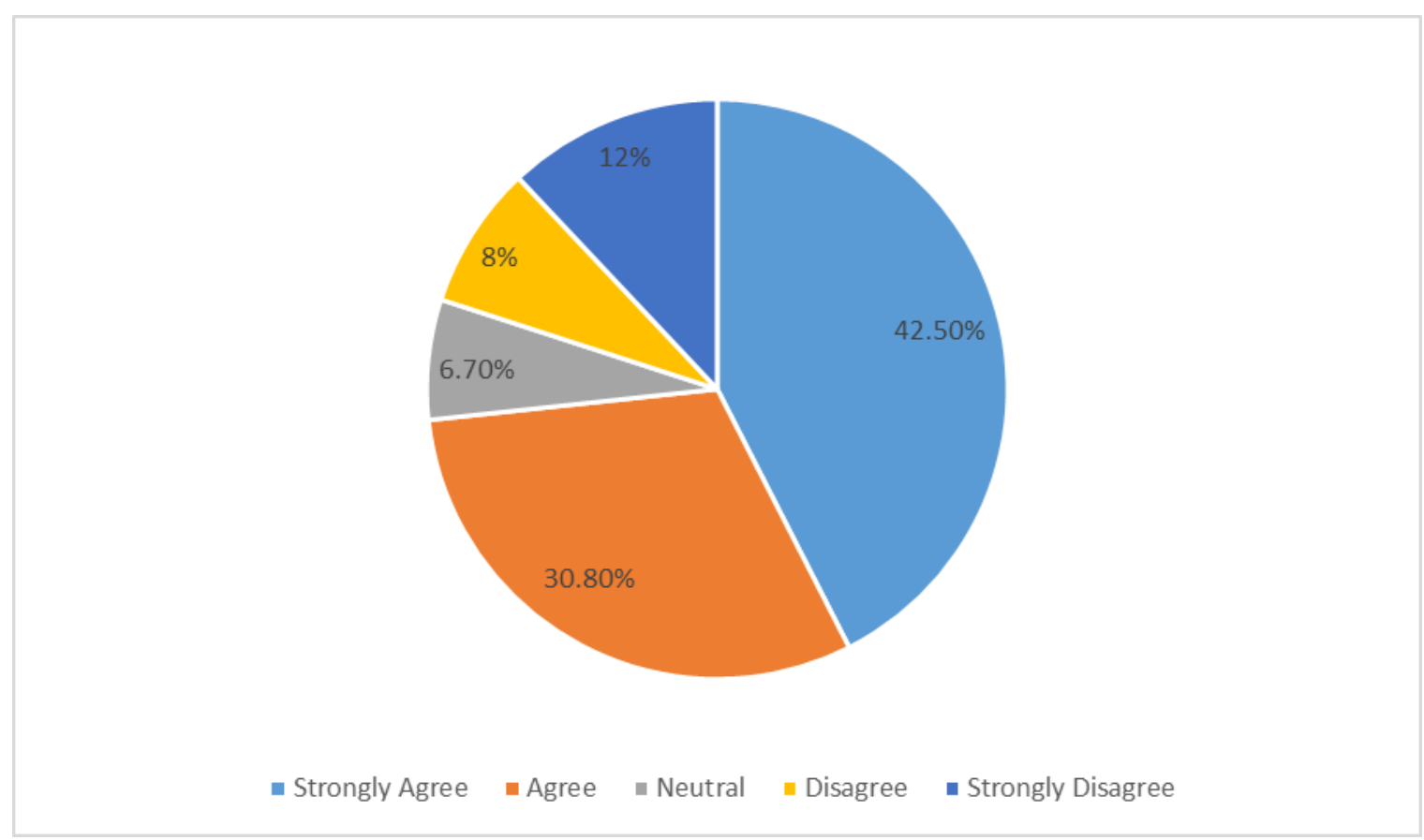

Figure 1. It is challenging to meet the demands of fast and slow learners in a typical classroom

It was also noted that participants overwhelmingly approved (strongly agree-42\% and agree-39\%) to the statement that differences in the ability to learn language among fast learners and slow learners pose a challenge to effective teaching of foreign language (Figure 2).

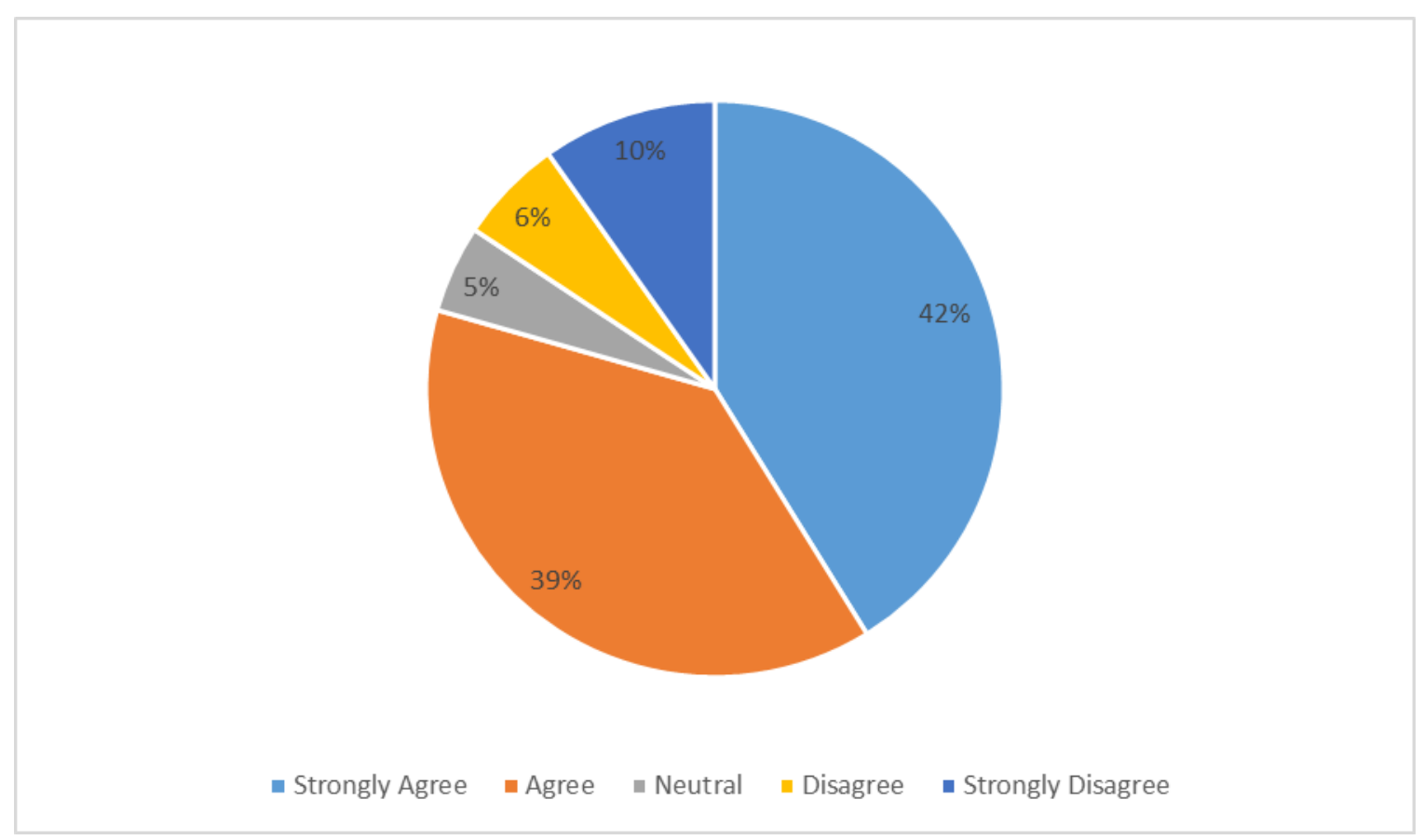

Figure 2. Differences in the ability to learn language between fast learners and slow learners pose a challenge to effective teaching of foreign language

Participants strongly agreed $(38.70 \%)$ and agreed $(30 \%)$ that slow learners have foreign language learning difficulties while fast learners learn language with ease (Figure 3). 


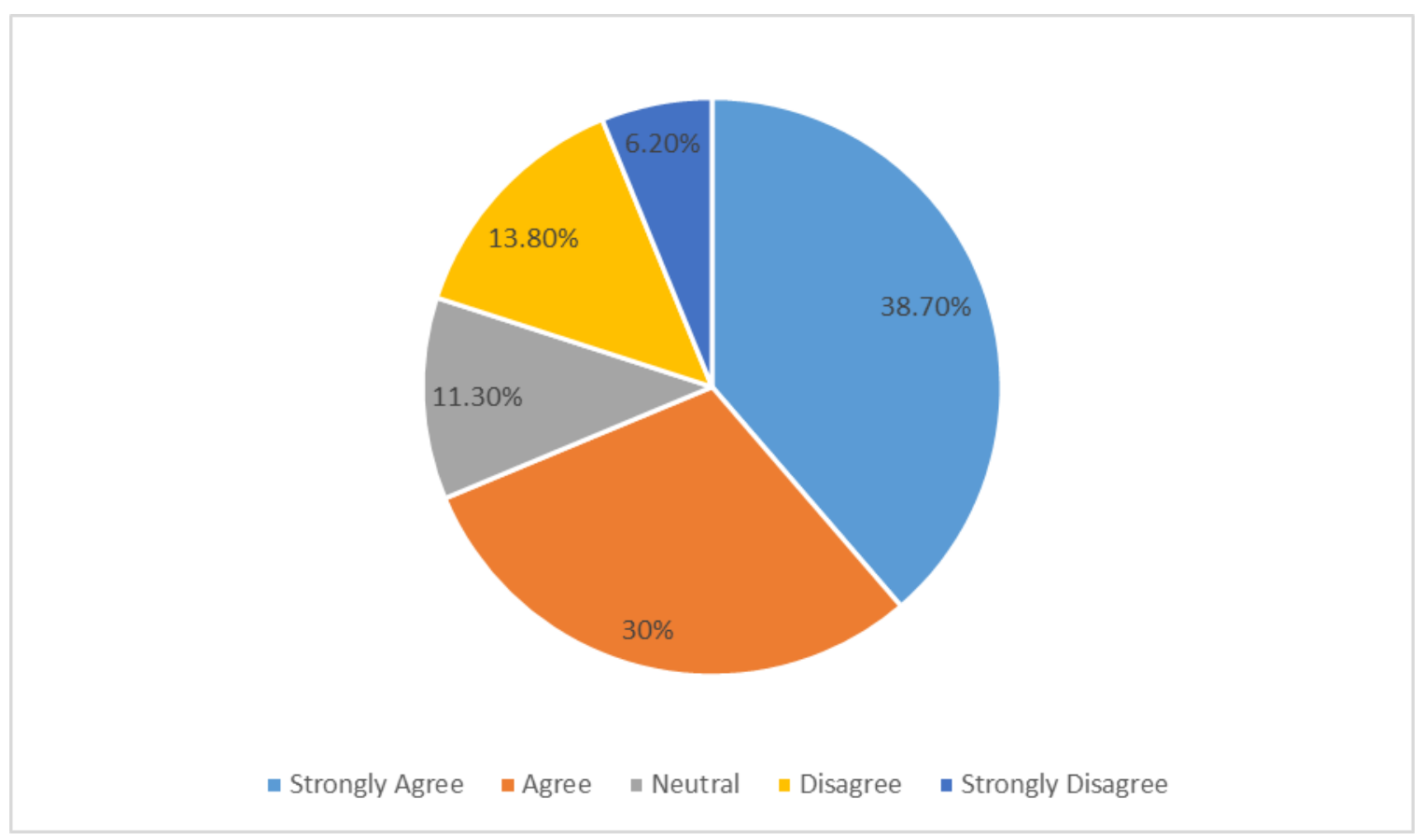

Figure 3. Slow learners have foreign language learning difficulties while fast learners learn language with ease

Participants overwhelmingly approved (strongly agree-32.50\% and agree-30\%) the statement that weaker students have a challenge in understanding orthographic/phonological aspects of language while fast students learn orthographic/phonological aspects of language with ease (Figure 4).

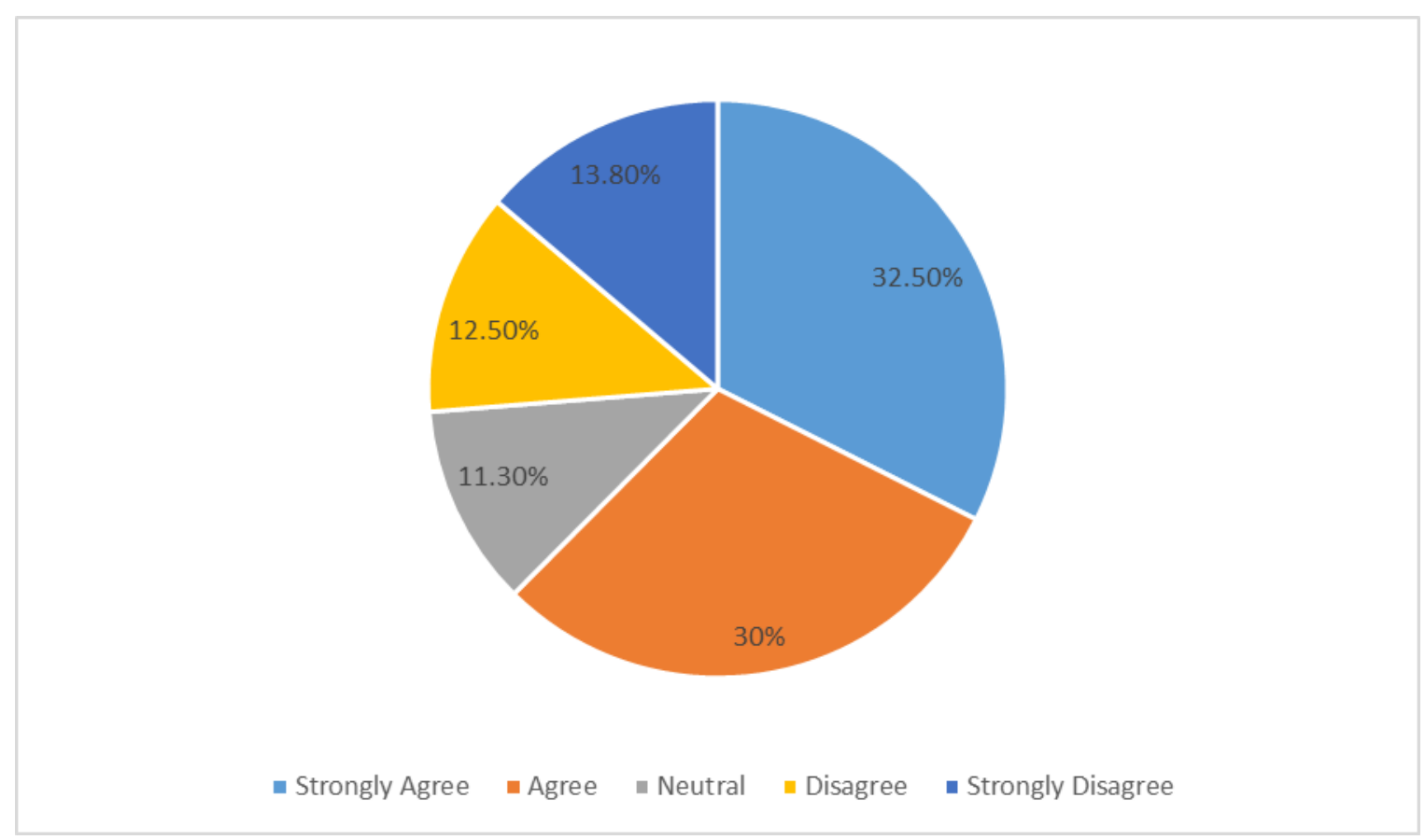

Figure 4. Weaker students have challenges in understanding orthographic/phonological aspects of language while fast students learn orthographic/phonological aspect of language with ease

Participants overwhelmingly (strongly agree- $41.30 \%$ and agree-32.50\%) approved the statement that slow learners have weaker foreign language aptitude that negatively impacts on foreign language acquisition: fast learners have strong foreign language aptitude (Figure 5). 


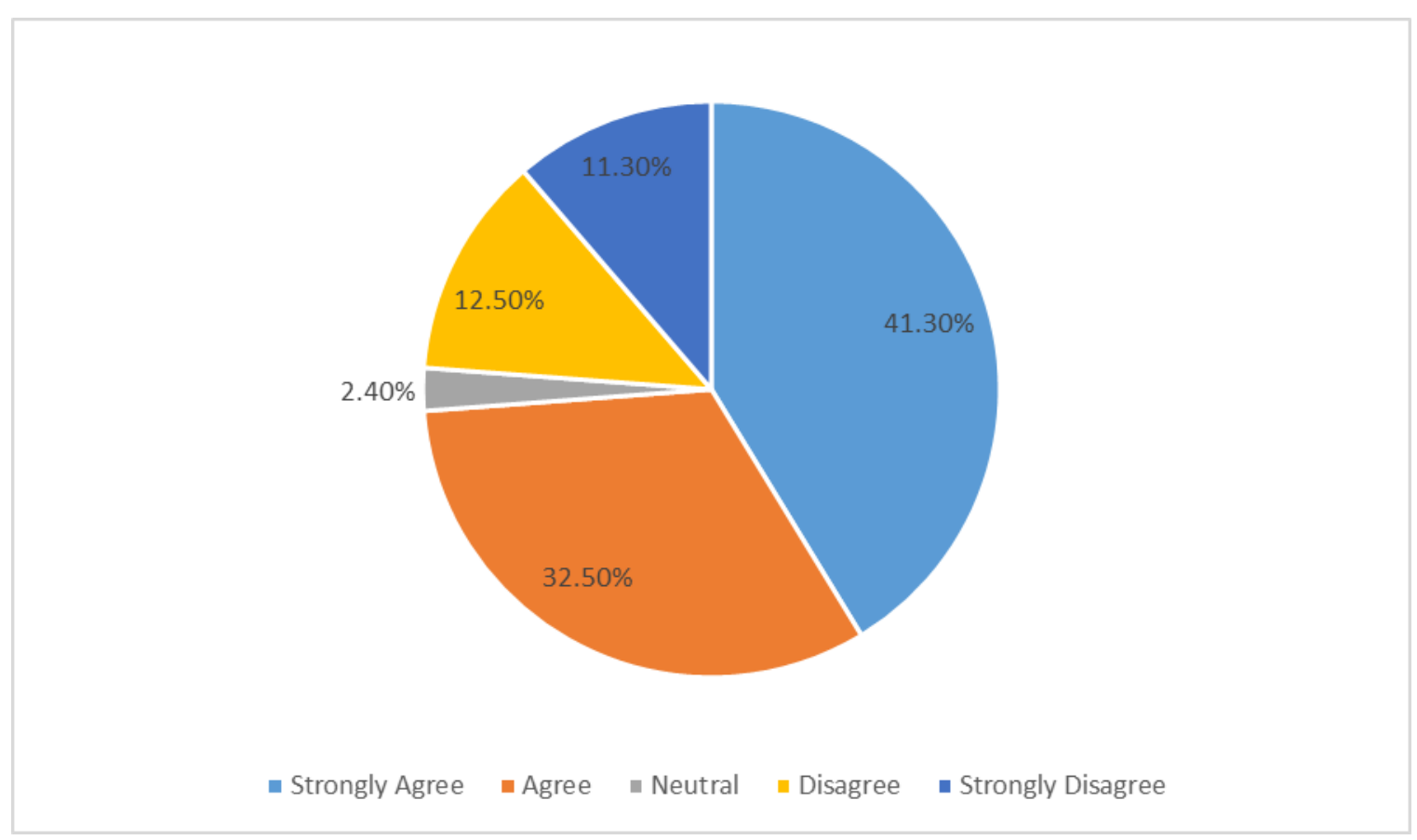

Figure 5. Slow learners have weaker foreign language aptitude that negatively affects foreign language acquisition: fast learners have strong foreign language aptitude

The majority of participants hold (strongly agree-35\% and agree-30\%) the view that mixed-ability classes tend to be uncooperative and fast learners get bored easily (Figure 6).

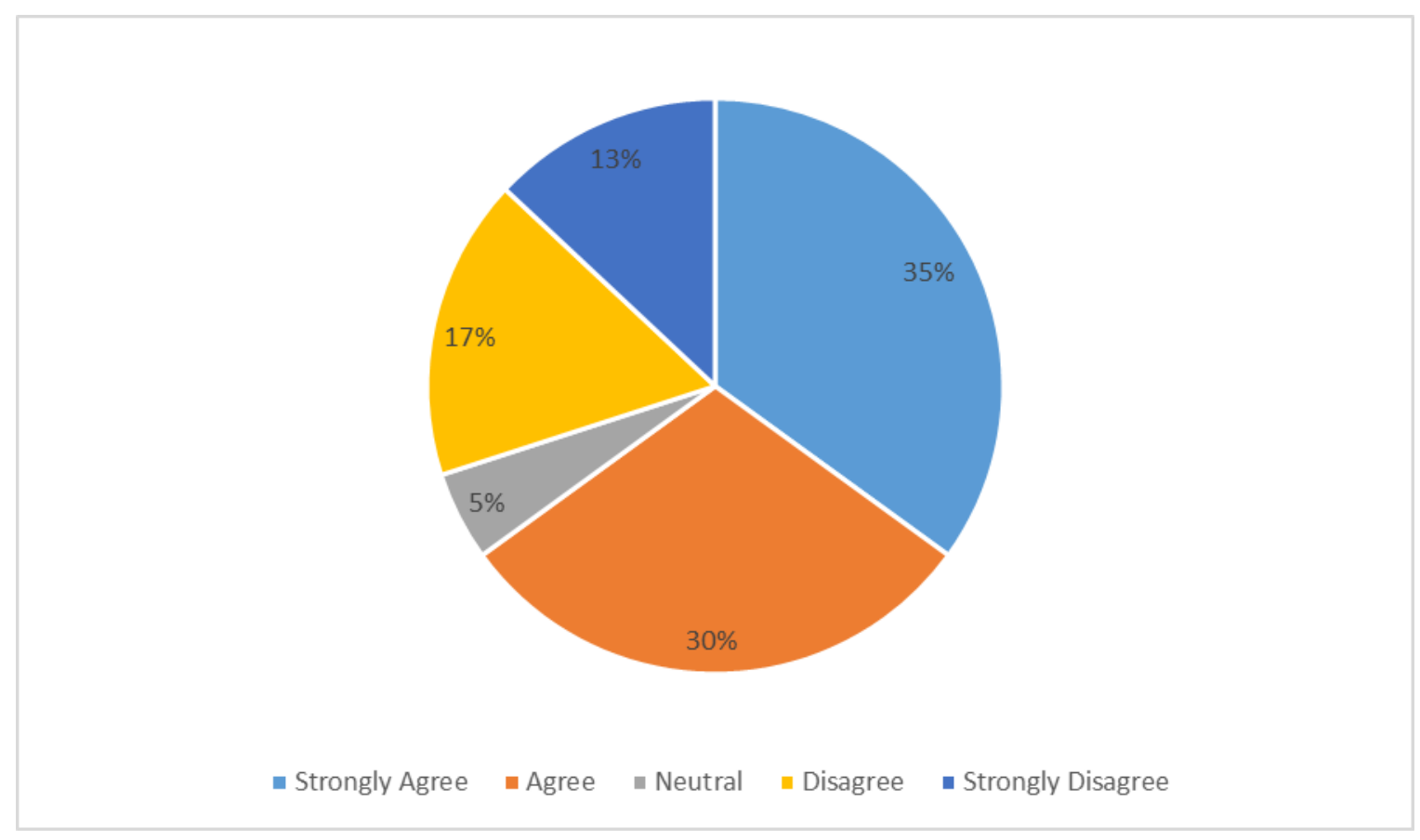

Figure 6. Mixed-ability class tends to be uncooperative and fast learners get bored easily

The majority of participants strongly agreed (40\%) or agreed (35\%) that it is challenging to plan for the lesson to teach a mixed-ability class (Figure 7). 


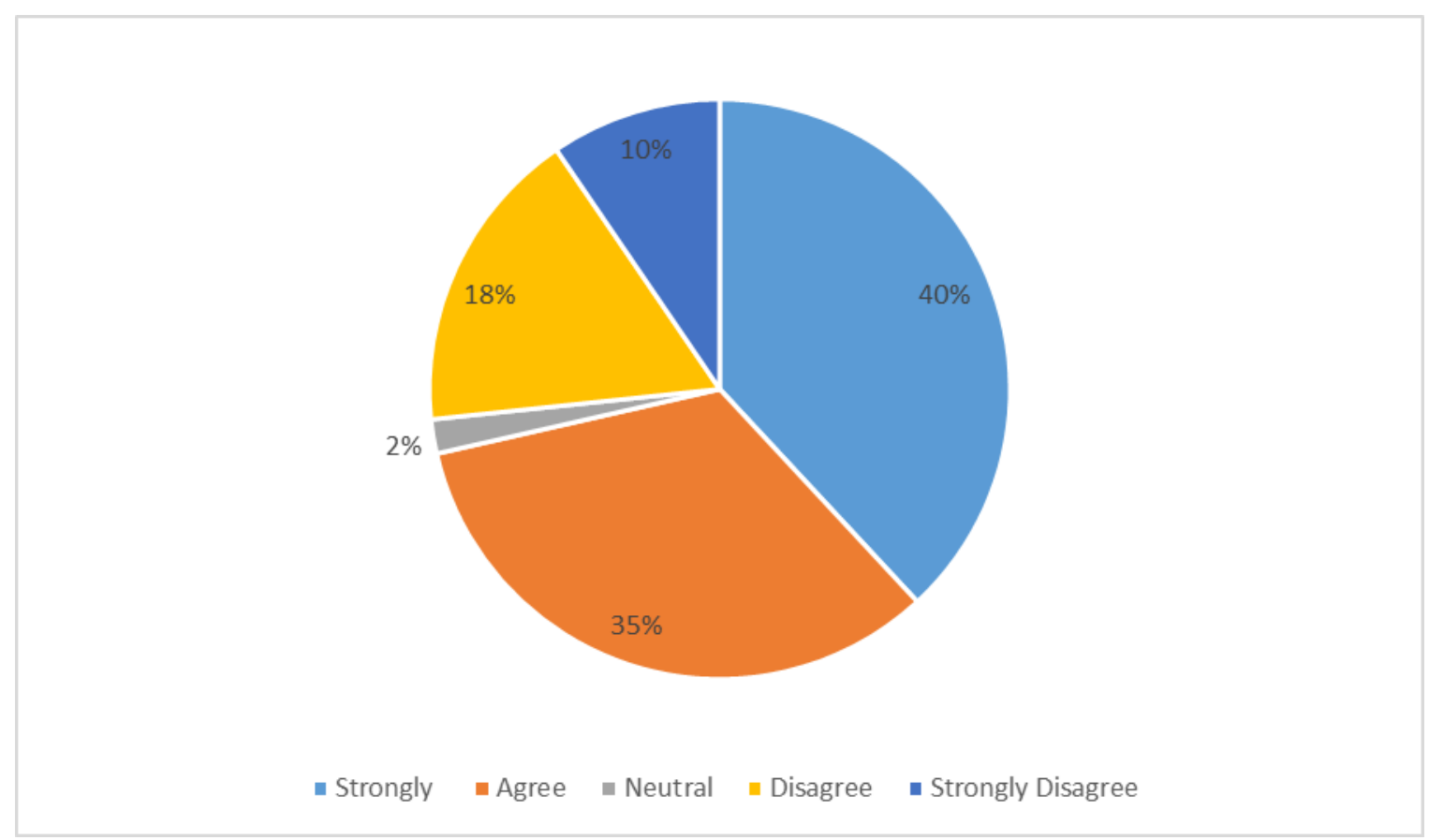

Figure 7. It is challenging to plan for the lesson to teach a mixed-ability classroom

The majority participants hold (strongly agreed $-38 \%$ and agreed-45\%) that it is challenging to create appropriate work-materials for the mixed-ability class (Figure 8 ).

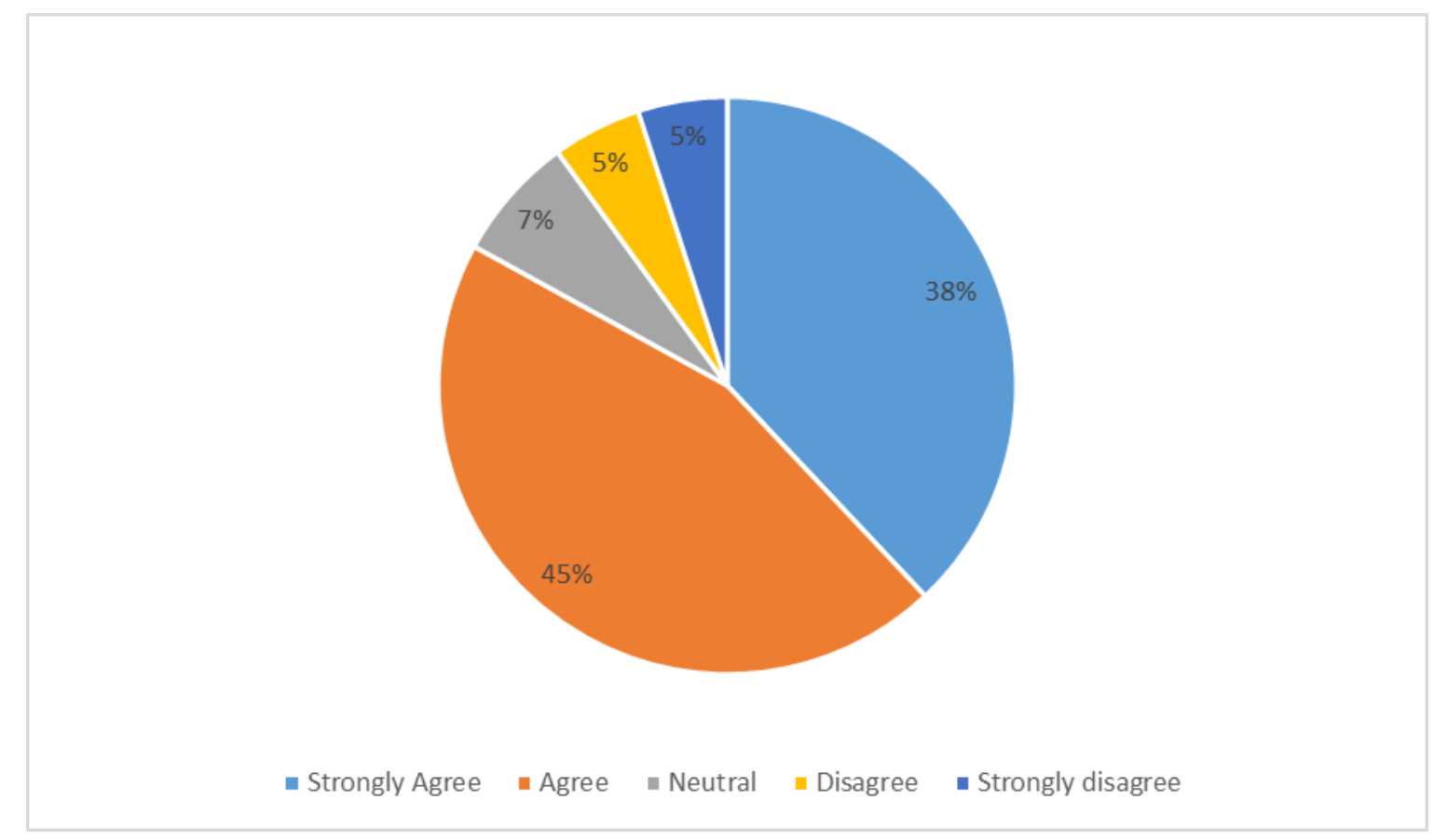

Figure 8. It is challenging to create appropriate work-materials for the mixed-ability class

Participants overwhelmingly (strongly agree- $46 \%$ and agree-41\%) approved the statement that there are hardly any ideal approaches to manage mixed-ability class (Figure 9). 


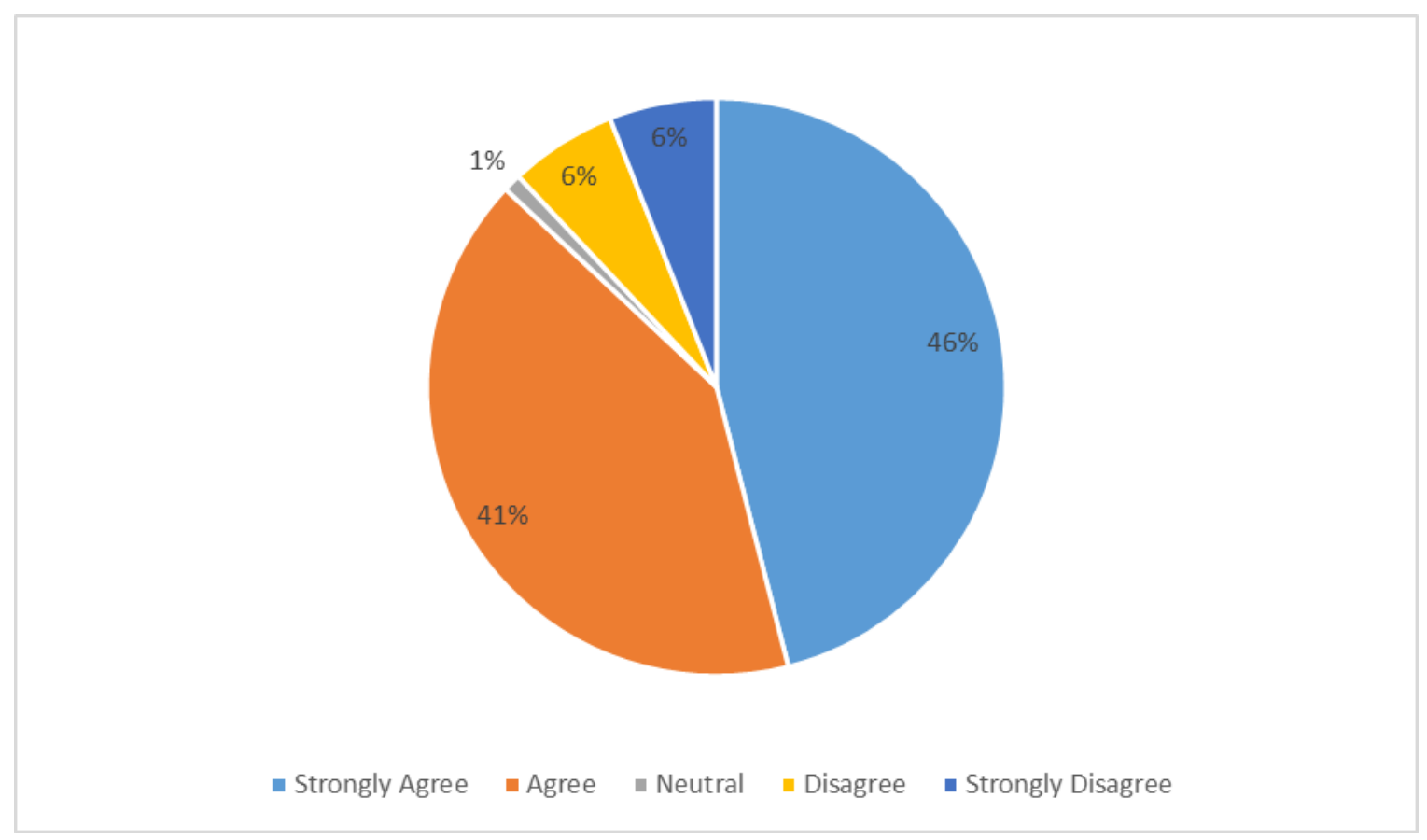

Figure 9 . There are hardly any ideal approaches to manage mixed-ability class

Participants strongly agree (42\%) and agree (33\%) that it is challenging to get the attention of all learners in a mixed-ability classes (Figure 10).

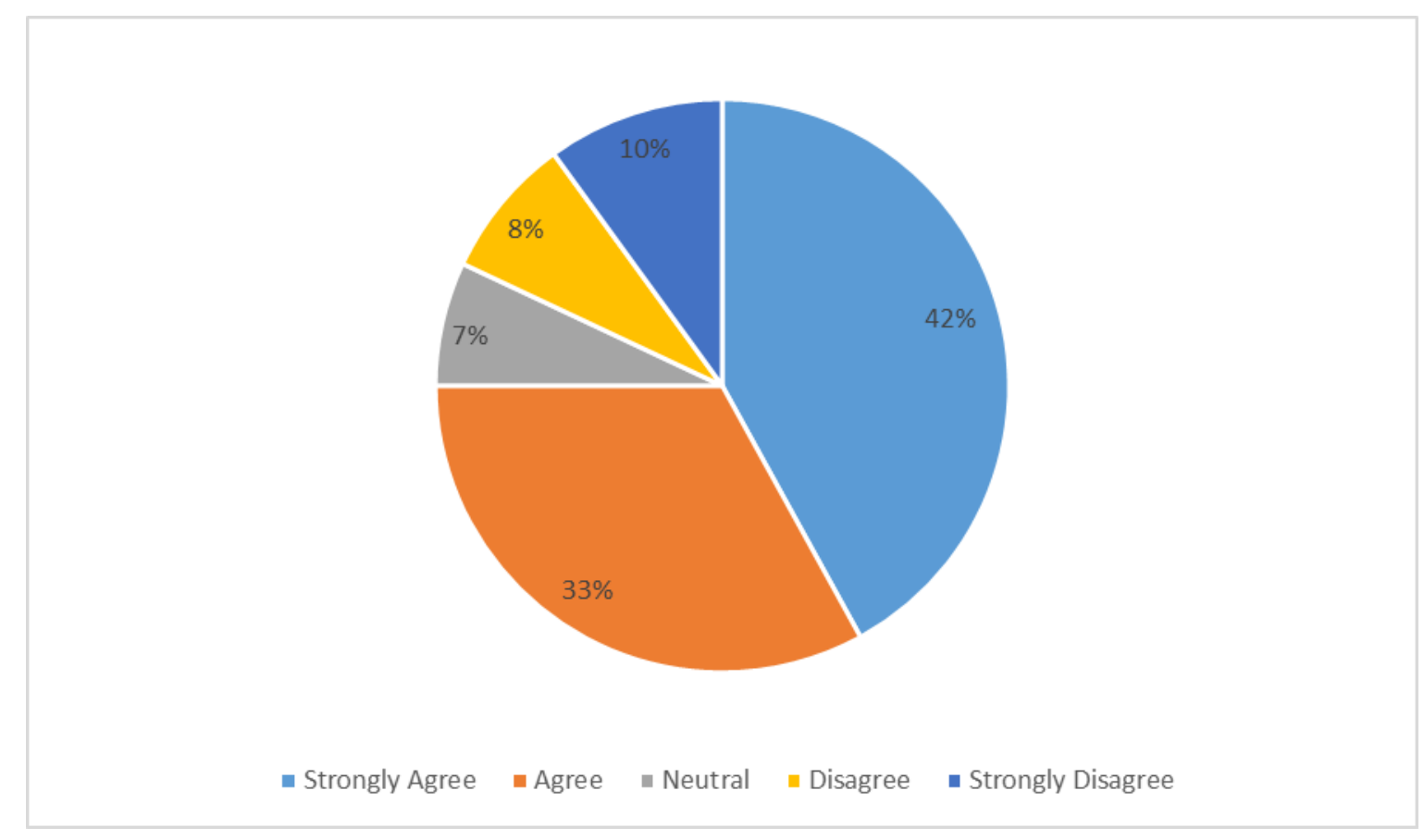

Figure 10. It is challenging to get the attention of all learners in mixed-ability classes

Participants overwhelmingly (strongly agree- $45 \%$ and agree-35\%) approved the statement that they feel frustrated when teaching mixed-ability classes because of low motivation of weak students (Figure 11). 


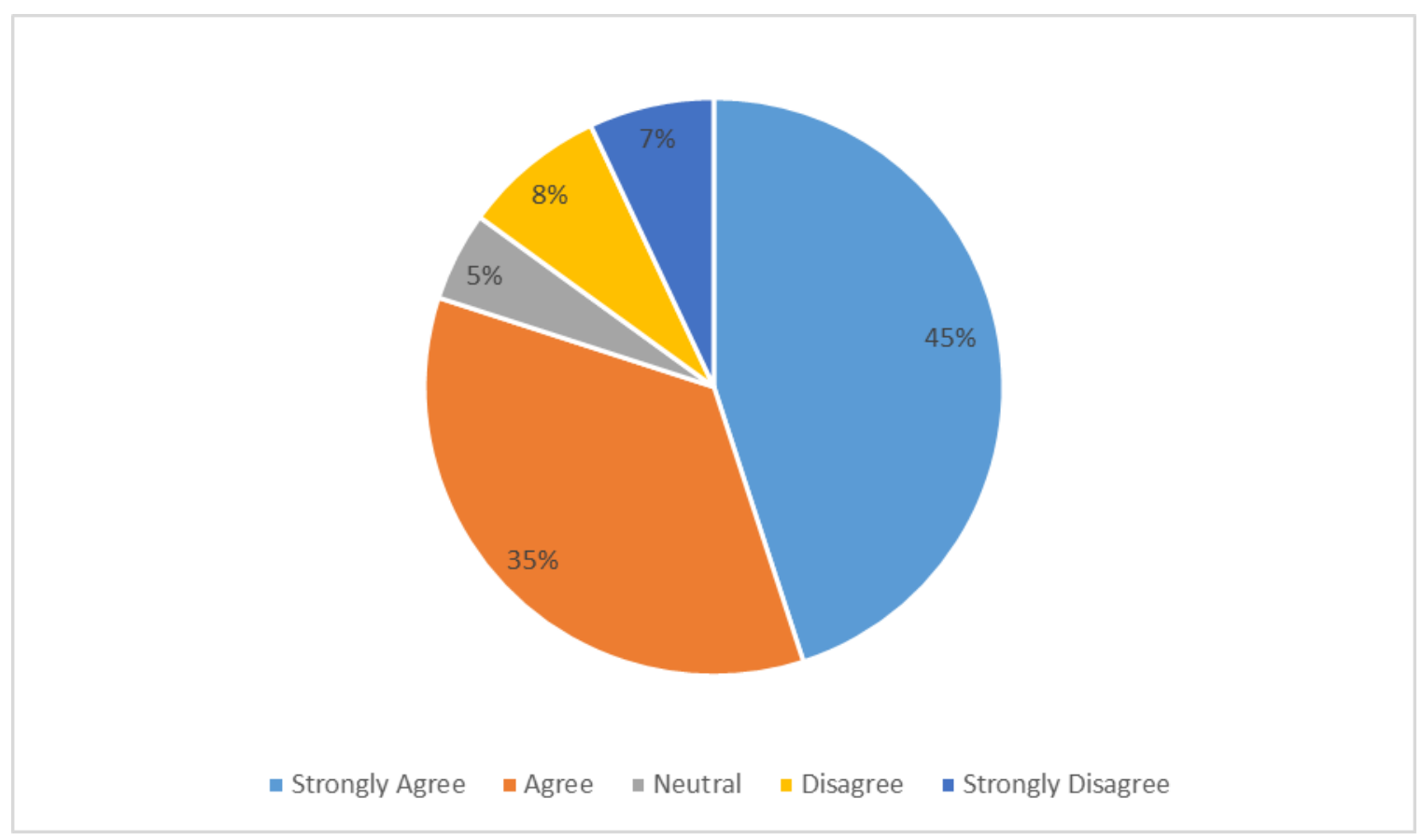

Figure 11. I feel frustrated when teaching mixed-ability class because of low motivation of weak students

\section{Discussion}

Results of this study confirm that differences exist between slow students and fast students in language learning and that these differences pose a hindrance to teachers when dealing with mixed-ability classes. Differences between slow students and fast students were identified: challenging to meet the demands of fast and slow learners, slow learners have foreign language learning difficulties while fast learners learn language with ease. Weaker students have a challenge in understanding orthographic/phonological aspects of language, while fast students learn orthographic/phonological aspects of language with ease; slow learners have weaker foreign language aptitude that negatively affects their foreign language acquisition: fast learners enjoy strong foreign language aptitude.

Challenges of teaching English language to learners of English in the UAE universities were identified: mixed-ability class tending to be uncooperative and fast learners get bored easily; challenging in planning for the lesson to teach a mixed-ability class; challenging in creating appropriate work-materials for the mixed-ability class; lack of best approaches to manage mixed-ability classes; challenging in getting attention of all learners in a mixed-ability classes; and frustration when teaching mixed-ability classroom because of low motivation of weak students. Results of the present study corroborate those reflected in previous studies (Hordiinko \& Lomakina, 2015; AI-Subaiei, 2017; Chou \& Luo, 2003; Svärd, 2006; Baker, 2002).

For example, HordiiHordiinko and Lomakina (2015) identified challenges of teaching mixed-ability class as teachers get frustrated when dealing with learners with mixed abilities. Svärd (2006) identified challenges of teaching mixed-ability classes as dealing with learners with different learning abilities; difficulty in getting attention of all learners; poor motivation by learners; frustration on the part of the teacher; uncooperativeness of learners; and difficulties in planning lessons and creating work-material. For Baker (2002) challenges of teaching English language to mixed-ability learners include attention issues; low motivation by students, and frustration on the part of teachers in their attempt to meet the demands of learners with mixed abilities.

AI-Subaiei (2017) highlighted that challenges experienced by English teachers when teaching mixed-ability English language classes noting that these challenges range from class management, motivation issues to inadequate learning materials. Moreover, challenges include meeting the needs of learners with different abilities and thus require instructors to employ effective management methods. This can be accomplished by using various methods in a bid to experiment with different strategies and settle on the most effective ones.

According to Al-Subaiei (2017), teachers who have a positive attitude towards the diversity in terms of students' abilities tend to be more successful in teaching mixed-ability classes. Al-Subaiei (2017), suggest that planning for 
specific tasks for various levels of ability for students can ensure that all learners are engaged in the learning process and this, in turn, ensures efficiency and success in teaching mixed-ability classes. Strategies that seem to work best were those that focused on students' needs and those strategies that made learners to be actively engaged in their learning processes. This is also referred to as student-centred approach to learning (AI-Subaiei, 2017).

For Rahman (2018), it is important for teachers of mixed-abilities foreign language teachers to regroup learners based on their levels of abilities, allocated resources and provide motivation based on their abilities, as well as provide clear instructions and engage in better classroom environment to achieve learning in mixed-ability classes. Recommendations have been made for providing adequate teaching materials and teacher training. Rahman specifically recommended that "teachers" have patience, teach slowly, offer clear instructions, be friendly, divide bigger parts into easier steps, whilst especially helping the weaker students. The teachers want to see the best possible classroom environment using the white board and overhead projector, repeating what is written, walking around the students, giving feedback, correcting their mistakes in a very friendly way, thus enhances self-confidence and gives them extra help. Finally, the study showed that teachers often face myriad of challenges while they rarely use the mentioned strategies to overcome the challenges.

According to Şalli-Çopur (2005), in order to solve the problems of mixed-ability classes, teachers need to ensure the teaching appeals to all senses, learning styles and all types of intelligence. Moreover, it should be based on a meaningful context for all learners. To exemplify this point, Şalli-Çopur (2005) proposes that visuals should be used that reflect all ages and proficiency levels, and that group-work activities for the students should be in cooperated to allow learners learn from each other. The argument is that allowing interaction between strong students with weaker students in mixed-ability classes can help the stronger ones to serve as a source of knowledge to weaker ones. Alternatively, teacher may form groups unique to weaker students and stronger students, and provide them with different tasks to allow more competent students to work on higher-level tasks, whilst the less competent students deal with simpler tasks.

Shrivastava (2010) suggests that English teachers training and workshop should also be arranged to familiarize them with various methods of conducting mixed-ability classes. In particular, English language teachers can create possible classroom environment for students to allow for shifting between a single teaching methods to various methods.

Other suggestions include teachers working on varying degrees of structured pedagogy that can be applied in the same class without letting students know that they are divided in groups based on their capabilities (Shrivastava, 2010). Shrivastava (2010) further recommends that teachers should employ various teaching methods and to encourage learners work in mixed ability groups to facilitate them to learn from each other.

\section{Conclusion}

Teachers teaching students in mixed-ability foreign language classes experience challenges. These challenges include mixed-ability classes tending to be uncooperative and fast learners get bored easily; challenging in planning for the lesson to teach a mixed-ability class; challenging in creating appropriate work-materials for the mixed-ability class; lack of best approaches to manage mixed-ability class; challenging in getting attention of all learners in mixed-ability classes; and frustration when teaching mixed-ability classroom because of low motivation of weak students.

The present study has some limitations. First, results cannot be generalizable beyond the UAE context given the use of convenience sampling which may limit the ability to generalize the research results of the study into a broader sample. Second, the taking of quantitative data through self-report measures may have created bias on the part of the participants as there is a possible that participants may have engaged in filling the questions for the sake of it to ensure they are completed as quickly as possible rather than provide honest responses. Future research should allow more time for similar studies and follow up with interviews with study participants to confirm their responses. Again, using qualitative methods, e.g., semi-structured interviews in future studies will help shed light on teachers' deeper explanations of the problems and reach better solutions from their perspectives. Therefore, there is a need for more research works to identify methods to help teachers of English language overcome these challenges.

\section{References}

Ansari, M. S. (2013). Coping with the Problems of Mixed Ability Classes: A Study in the Context of Teaching English as SL/FL. International Journal of English: Literature, Language \& Skills.

AI-Subaiei, M.S. (2017). Challenges in Mixed Ability Classes and Strategies Utilized by ELI. Teachers to Cope with Them. English Language Teaching; 10(6):182-189. Retrieved on 19th Dec 2019 from 
https://www.researchgate.net/publication/317241644_Challenges_in_Mixed_Ability_Classes_and_Strategies_U tilized_by_ELI_Teachers_to_Cope_with_Them. https://doi.org/10.5539/elt.v10n6p182

Al-Shammakhi, F., \& Al-Humaidi, S. (2015). Challenges Facing EFL Teachers in Mixed Ability Classes and Strategies Used to Overcome Them. World Journal of English Language, 5(3). Retrieved on 19th Dec 2019 from http://wjel.sciedupress.com. https://doi.org/10.5430/wjel.v5n3p33

Baker, J. (2000). The English language teacher's handbook: how to teach large classes with few resources. New York: Continuum; London: Cassel.

Borah, R. (2013). Slow Learners: Role of Teachers and Guardians in Honing their Hidden Skills. International Journal of Educational Planning \& Administration, 139-143. Retrieved on 19th Dec 2019 from https://www.ripublication.com/ijepa/ijepav3n2_04.pdf

Billy, P.P. (2016). Coping with slow learners. International journal of management and applied science, 2(12), 56-58. Retrieved on 19th Dec 2019 from http://www.auteachereducation.org/images/conf_book_2018.pdf

Brown, D. H. (2002). Strategies for Success: a practical guide to learning English. New York: Longman.

Chapman, C., \& King, R. (2003). Differentiated instructional strategies for reading in the content areas. Thousand Oaks, CA: Corwin Press.

Chou, K., \& Luo, B. (2003). Effects of leveled and mixed ability grouping on English learning motivation in Taiwanese elementary education. Conference: Proceedings of the 20th International Conference on English teaching and Learning in the Republic of China.

Hordiinko, N.M., \& Lomakina, L.V. (2015). Teaching EFL to Mixed-Ability Classes: Strategies, Challenges, and Solutions. Advanced Education, 3, 38-42. Retrieved on 19th Dec 2019 from http://ae.fl.kpi.ua/article/view/44198. https://doi.org/10.20535/2410-8286.44198

Holden, B. (2002). Listen and Learn, English Teaching Professional, Issue 23, pages 18-20

Hedge, T. (2000). Teaching and learning in the language classroom. Oxford, UK: Oxford University Press.

Ganschow, L., Sparks, R.L., \& Javorsky, J. (1998). Foreign Language Learning Difficulties: An Historical Perspective. Journal of Learning Disabilities, 31(3), 248-258. Retrieved on 19th Dec 2019 from https://www.ncbi.nlm.nih.gov/pubmed/9599957. https://doi.org/10.1177/002221949803100304

Ganschow, L., Sparks, R., Javorsky, J., Pohlman, J., \& Bishop-Marbury, A. (1991). Identifying native language difficulties among foreign language learners in college: A "foreign" language learning disability? Journal of Learning Disabilities, 24, 530-541. Retrieved on 19th Dec 2019 from https://www.ncbi.nlm.nih.gov/pubmed/1765728. https://doi.org/10.1177/002221949102400905

Humes-Bartlo, M. (1989). Variation in children's ability to learn second languages. https://doi.org/10.1017/CBO9780511611780.004

In K. Hyltenstom \& L. Obler (Eds.), Bilingualism across the life span (pp. 41-54). Cambridge, MA: Cambridge University Press.

Khan, S.M. (2008). Education of slow learner. Retrieved 25 July 2018 from http://research-educationedu.blogspot.com/search/label/Education\%20of\%20Slow\%20LeaRner

Lightbown, P., \& Spada, N. M. (2006). How languages are learned. Oxford University Press, USA.

Lightbown, P.M., \& Spada, N. (1997). How Languages are Learned. Oxford, Oxford University Press.

May, T. (1993). Social Research: Issues, Methods, and Process. Buckingham: Open University Press.

Muppudathi, G. (2014). Role of Teachers on Helping Slow Learners to bring out their Hidden Skills. International Journal of Scientific Research, 3(3), 98-99. Retrieved on 19th Dec 2019 from http://www.iosrjournals.org/iosr-jrme/papers/Vol-6\%20Issue-6/Version-7/E0606072326.pdf

Nunan, D. (2000). Language Teaching Methodology, Harlow, Pearson Education Ltd. Page 171

Oxford, R. (1990). Language Learning Strategies, Boston, Heinle and Heinle Publishers

Rahman, M. (2018) Teaching English Language to the Mixed-ability Classes at the HSC Level in Bangladesh: Challenges and Probable Solutions. International Journal of Ethics in Social Sciences, 6 (1) 29-50. Retrieved on 19th Dec 2019 from http://www.crimbbd.org/wp-content/uploads/2018/12/6.1.3a.pdf 
Şalli-Çopur, D. (2005). Coping with the Problems of Mixed Ability Classes. The Internet TESL Journal, Vol. XI, No. 8, Middle East Technical University (Ankara, Turkey). Retrieved on 19th Dec 2019 from http://iteslj.org/Techniques/Salli-Copur-MixedAbility.html

Sailaja, S.S. (2018). ELT in Mixed Ability Classrooms-Teacher Challenges and Strategies in the Rural Context. International Journal of Academic Research, 5(11). Retrieved on 19th Dec 2019 from http://ijar.org.in/stuff/issues/v5-i11/v5-i11-a004.pdf

Shrivastava, A. (2010). Coping with the Problems of Mixed Ability Students. Language in India. Vol.10. Retrieved on 1 July 2018 from www.languageinindia.com 10.

Sparks, R., \& Ganschow, L. (1996). Teacher's perceptions of students' foreign language academic skills and affective characteristics. Journal of Educational Research, 89, 172-185. Retrieved on 19th Dec 2019 from https://www.tandfonline.com/doi/abs/10.1080/00220671.1996.9941323. https://doi.org/10.1080/00220671.1996.9941323

Svärd, A. (2006). The challenge of mixed-ability classes. How should upper secondary English teachers work in order to help the weaker students?

Sparks, R., Ganschow, L., \& Javorsky, J. (1992). Diagnosing and accommodating the foreign language learning problems of college students with learning disabilities. Learning Disabilities Research and Practice, 7, 150-160. Retrieved on 19th Dec 2018 from https://psycnet.apa.org/record/1992-44933-001

Service, E. (1992). Phonology, working memory, and foreign language learning. Quarterly Journal of Experimental Psychology, 45A, 21-50. Retrieved on 19th Dec 2018 from https://journals.sagepub.com/doi/10.1080/14640749208401314 . https://doi.org/10.1080/14640749208401314

Valentic, D. (2005). ELT in multi-level classes. Hupe Newsletter, 23.Lescano, A.A. (1995). The remedial English project. English Teaching Forum, 33(4). 